\title{
The Effects of Ad Model Ethnicity on Advertising
}

\author{
Haryadi Arief Nuur Rasyid ${ }^{1, a)}$ \\ ${ }^{1}$ Universitas Muhammadiyah Yogyakarta \\ aharyadiariefnuurasyid@yahoo.co.id \\ aharyadiariefnurrasyid@umy.ac.id
}

Article Info

Article history:

Received 22 March

2019

Revised 20 April

2019

Accepted 02 May

2019

\begin{abstract}
Development of communication and transportation technology has customized the appearance of multicultural marketing environments. The condition causes changes in advertising practices as one of the disciplines that have long been used in promotional practices. In many countries with a multiethnic population, advertising practices based on the melting-pot theory began to be questioned. Some research started to answer the doubts of theoretical assumptions of the melting-pot theory on the situation of multicultural marketing. Among them is the research conducted by Christina Kwai-Choi Lee and his friends with a multi-ethnic social background of New Zealand. This research, referring to that research, tests the model developed by Lee and his friends, by taking a multi-ethnic social background in Indonesia. This research focuses on the use of ad models ethnicity in advertising and usesexperimental laboratory method with $2 \times 2$ between-subject factorial design. The factors that are manipulated are ad models ethnicity (Chinese ad model versus Javanese ad model) and product ethnicity category (Chinese ethnic product versus Javanese ethnic product). Participants used are 160 female students from SMA Steladuce 1 Yogyakarta. The result shows that the presence of Chinese ethnicity in the predominantly Javanese environment leads to individuals from Chinese ethnicity become more sensitive to referencing themselves to an advertisement with Chinese models (H-1). Furthermore, an individual's self-referencing to the advertisement with a model that fits with an individual's ethnicity might affect individual attitude in advertising (H-2a, H-2b, H-2c). This study indicates that the Javanese product can moderate self-referencing of individual consumers to an advertisement that uses a model from Chinese ethnicity (H-3a and $\mathrm{H}-3 \mathrm{~b})$
\end{abstract}

Keywords: self-referencing; attitude; ad models ethnicity; product ethnic category.

\begin{abstract}
ABSTRAK
Perkembangan teknologi komunikasi dan trantsportasi telah mengkondisikan munculnya lingkungan pemasaran yang bersifat multikultural. Kondisi tersebut menyebabkan adanya perubahan praktik periklanan sebagai salah satu disiplin yang sudah lama digunakan dalam praktik promosi. Di berbagai Negara dengan populasi yang bersifat multi etnis, praktik periklanan yang berlandaskan pada melting-pot theory mulai dipertanyakan. Beberapa penelitian mulai dilakukan untuk menjawab keraguan asumsi teoritis dari melting-pot theory pada situasi pemasaran yang bersifat multikultur. Di antaranya adalah penelitian yang dilakukan oleh Christina Kwai-Choi Lee dan kawan-kawan dengan latarbelakang social negara New Zealand yang bersifat multietnis. Mengacu pada penelitian tersebut, pada penelitian ini akandilakuan pengujian terhadap model penelitian yang dikembangkan oleh Lee dan kawan-kawan, dengan mengambil latarbelakang sosial di Indonesia yang bersifat multietnis. Penelitian ini memfokuskan diri pada penggunaan model iklan kesukuan di dalam periklanan. Peneliti menggunakan metode eksperimen laboratorium dengan desain factorial antar subyek 2x2. Faktor-faktor yang dimanipulasi adalah kesukuan model
\end{abstract}


iklan (model iklan Tionghoa versus model iklan Jawa) dan kategori produk kesukuan (produk kesukuan Tionghoa versus produk kesukuan Jawa). Partisipan yang digunakan adalah 160 siswa perempuan dari SMA Steladuce 1 Yogyakarta. Hasil penelitian menunjukkan bahwa keberadaan kesukuan minoritas Tionghoa di dalam lingkungan kesukuan mayoritas Jawa menyebabkan individu dari kesukuan minoritas Tionghoa menjadi lebih sensitif di dalam memberikan pengacuan diri terhadap iklan dengan model iklanTionghoa (H-1). Hasil dari penelitian ini juga menunjukkan bahwa pengacuan diri individu terhadap iklan dengan model iklan yang sesuai dengan kesukuan individu dapat mempengaruhi sikap individu di dalam periklanan $(\mathrm{H}-2 \mathrm{a}, \mathrm{H}$ 2b, $H$-2c). Selanjutnya hasil dari penelitian ini menunjukkan bahwa keberadaan produk dari kesukuan mayoritas Jawa dapat memoderasi pengacuan diri individu konsumen terhadap iklan yang menggunakan model iklan dari kesukuan minoritasTionghoa (H-3a dan $H-3 b)$

Keywords: pengacuan diri; sikap; model iklan kesukuan; kategori produk kesukuan.

\section{INTRODUCTION}

As one of the most often and longest used discipline in promotional practice, advertising has developed many traditions. One of the flourish traditions in advertising tradition is an assumption that advertisers are likely to achieve promotional success by merely exerting one strategy that works for one specific ethnic for reaching all ethnicities in the social environment with various ethnicities (Lee et al., 2002). The assumption is found in Melting Pot Theory that claims that a particular ethnic individual who settles in a specific majority ethnicity will adjust himself with the majority way of thinking and behavior (Kinra in Lee at al., 2002). In the practice of advertising, the melting-pot theory assumes that individuals from a minority group will respond to an ad in the same way as the majority does, even if the practice is addressed to the majority group. However, the theoretical assumption has started to cast doubt by many scholars because of current global economics.

The advent of that economic challenge, caused by the development of information technology and transportation, breeds homogenized market identity in the global society (Lee et al., 2002). On the one hand, from the advertiser perspective, the condition has made global economic identic with broader market competition. Advertisers face more enormous challenges in fighting for consumer attention. In this vein, the advertisers are limited for segmenting the market. On the other hand, from the perspective of the consumer, the global economic condition mostly considers consumers to be a target market that has been educated concerning the products which have been more diverse or experienced overexposed information.

The abundance of information imposes the advertisers to be more capable in dealing with their multicultural market environment or multicultural marketing (Cui, 1997). Consequently, every advertiser is required to create a more fruitful market communication. The crucial issue now then is not to find the more effective and efficient promotional mix but also to maximalize each marketing communication device more optimally and creatively. One of the marketing communication devices which need to be optimally used is advertising. Advertisers should be more creative in augmenting ethnicity aspect so that advertising performed will be more effective.

Concerning the issue mentioned, there is plenty of research which has tried to demonstrate the existence of ethnicity aspect in the advertising. Until 2007, in the United States, there are more than 21 empirical studies which relate to ethnicity aspects in the ad (Torres \& Briggs, 2007). Some studies that have been performed showed that employing ethnic characteristic in the promotion could affect the effectivity of advertising conducted. Consumer's respond on advertising could be seen from their aspects of ethnicity which operates in the consumer as the preceptor or in the ad itself as the stimulus responded by the consumers (Dimofte et al., 2004). In light of that, two studies focused on the use of ad model ethnicity in the multicultural advertising environment. Those two studies were conducted by picking social background in New Zealand (Lee et al. 2002 and Martin et al., 2004). Likewise, Indonesia has a similar characteristic relating to social context, especially in its ethnic and cultural diversity. Indonesia is a country with an increased number of a multiethnic or multicultural population. One of the prominent ethnic minorities in the Indonesian social dynamic is Chinese, 
especially in the environment where Javanese is the majority. In line with findings from two research in New Zealand, this research attempts to answer the question: "could theoretical model that explains the effect of the use of ad ethnicity model of consumer behavior used in the New Zealand advertising be applied to reflect the practice of advertising which involves Chinese ethnicity in the Javanese environment on Indonesian social background?

\section{Method}

The research conducted a laboratory experiment with between-subject factorial design $2 \times 2$. In the experimental design matrix, it would look like this:

Table 1.Experimental design matrix

\begin{tabular}{|c|c|c|c|}
\hline & & \multicolumn{2}{|c|}{ Product ethnicity } \\
\hline & & Chinese & Chinese \\
\hline \multirow{2}{*}{$\begin{array}{l}\text { Model } \\
\text { Ethnicity }\end{array}$} & Chinese & $\begin{array}{c}\text { Group 1: } \\
\text { An experimental group } \\
\text { unconcealed by } \\
\text { advertisements that use } \\
\text { Chinese ad ethnicity model } \\
\text { and product ethnicity } \\
\text { categories }\end{array}$ & $\begin{array}{c}\text { GRUP 2: } \\
\text { An experimental group } \\
\text { unconcealed by advertisements } \\
\text { that use Chinese ad ethnicity } \\
\text { model and Javanese product } \\
\text { ethnicity categories }\end{array}$ \\
\hline & Chinese & $\begin{array}{c}\text { GRUP 3: } \\
\text { An experimental group } \\
\text { unconcealed by } \\
\text { advertisements that use } \\
\text { Javanese ad ethnicity model } \\
\text { and Chinese product ethnicity } \\
\text { categories }\end{array}$ & $\begin{array}{c}\text { GRUP 4: } \\
\text { An experimental group } \\
\text { unconcealed by advertisements } \\
\text { that use Javanese ad ethnicity } \\
\text { model and product ethnicity } \\
\text { categories }\end{array}$ \\
\hline
\end{tabular}

Manipulated factors in the experiment performed were ad ethnicity model (Chinese and Javanese ad models) and product ethnicity category (Chinese and Javanese product ethnicity category). Manipulations towards experimental factors to develop stimuli of experimental advertisements were carried out through two stages of the pretest. The first pretest was to identify Chinese product ethnicity (ethnic product) and Javanese ethnic products (non-product ethnicity). The researcher discriminated various items advertised in the magazines, including Gadis, Aneka, Cosmo Girl Indonesia, and Gogirl. After analyzing several editions of those magazines, the researchers successfully discovered 19 products which came from three product categories (Women cosmetic, women fashion and fashion accessories, teenage girl supplement). The measurement used in the first pretest referred to the previous study by Martin et al. (2004). The research investigated 34 high school female students who were either Chinese or Javanese ethnicity or someone outside research participant as the respondents. It used a five-level semantic differential scale, ranging from not suitable to extremely suitable. Respondents were asked to appraise their suitability with 19 products listed provided that those items were advertised using both Chinese and Javanese ad model. Based on Paired sample t-test, products perceived to be Chinese product ethnicity in pretest 1 is highlight kit while for Javanese product ethnicity is Batik fashion.

The second pretest was to test Chinese and Javanese ethnicity model. The second pretest began with finding the professional advertisements of batik clothing and highlight kit. By referring to those divisions, the researcher sought for 18 model advertisements comprised both 9 Chinese and Javanese ad ethnicity model. Each model split into three groups, individually consisted of 3 models. Furthermore, the researcher hired a professional photographer to conduct a photography session for ad models determined. By doing so, the researcher collected six pictures of the ad model, which comprised of both three Chinese and three Javanese advertisements ethnicity model which each image 
was performed by three models. Those six pictures were color printed, and in each photo, notably to the below the photo, a question aiming to measure physical attractiveness of a group of ad model which displayed in the pictures was written. The scaling technique was seven-level semantic differential scale, ranging from extremely unattractive in the most left to extremely attractive in the most right (Martin et al., 2004). Physical attractiveness test of ad model, which are in the six pictures was carried out to sixty-one respondents who were high school girl students from Chinese and Javanese ethnicity and outside the research participant. Generally, those 61 respondents consisted of 29 and 32 responded coming from Chinese and Javanese ethnicity, respectively.

The next step was developing scripts and designs for four experimental advertising stimuli. In developing it, the researcher used the layout of Batik professional ads as the layout master for four experimental stimulus ads in the research. The ad forms choice, color, font, and verbal or visual layout component was created precisely similar to the professional one. Likewise, the ad script used was compounded as closed as in the professional batik and highlight kit advertisements. Some appropriation was merely performed in terms of brands. In the research, the brand for batik was changed into a fictional name "Batik Modis" while for highlight kit is transformed into "Realight."

The research investigated 160 participants picked from Steladuce I Senior High School Yogyakarta. This school is a single-sex secondary education so that all of the students were girls. The high school was selected purposively because Javanese and Chinese students were well-distributed in the school. One hundred sixty participants registered in this experiment were divided into four experimental groups that individually consist of forty individuals. Each group experiment was composed equally between Chinese and Javanese participant. Each experimental group consisted of twenty Chinese and twenty Javanese participants. Procedure performed for determining individual membership into an experiment group was by random assignment. Subsequently, the researcher entered into six classes alternately with the teacher permission and asked each student to fill the paper and pencil instrument according to their memberships in the experiment group.

\section{ANALYSIS}

\section{Multicultural Marketing Environment with Various Ethnicity}

In the marketing, from the advertiser perspective, the consequence of the market with various ethnicity will complicate the advertiser in deciding a strategy used. In that vein, the advertiser should sharpen their sensitivity to analyze how the market heterogeneity affect consumer response on each marketing stimuli used (Wooten, 1995)

Concerning diverse ethnicity in the market, there is a phenomenon that shows that individuals who come from an ethnic minority tend to be identifying themselves socially and culturally according to their ethnicities.Hence, the aspects of ethnicity which are not consistent with theirs and represented in the communication message, such as advertisements, will be sensitive for them (Dimofte et al., 2004). According to that conceptual framework, individuals are likely to pay heed to communication messages that include aspects of ethnicity that correspond with theirs. Furthermore, it informs that each consumer will always perceive themselves in a specific ethnicity. In turn, individual membership from an ethnicity group will carry themselves to self-identify their ethnicity in a different way to other individuals who settle in the same ethnicity. The conception that describes that situation is famously known as ethnicity concept.

\section{The relevance of the theoretical assumption of the melting-pot theory}

The salience of ethnic minority groups in the multicultural global society establishes a preliminary premise to question the theoretical assumption of melting pot theory. According to melting-pot theory, individuals from a minority group will respond to an ad in the same way as the majority does, even if the practice is addressed to the majority group. In this environment of the multicultural global market, that theoretical assumption is started to be doubted. In many countries with the condition mentioned, individual consumers tend to be more courageous in accentuating their ethnic identity although they come for an ethnic minority; a situation that is not consistent with melting-pot theory' theoretical assumption. Facing the problem, some scholars attempt to depict the tendency of advertising practice in the multicultural global marketing by referring to identification theory, distinctiveness theory, and schematic incongruity theory by improving self-referencing concept in the advertising. 


\section{Identification Theory}

Theoretical assumption of identification theory states that automatically individuals will appraise their level of identity within themselves with other sources they face in a particular social interaction (Hovlan and Weiss, 1951 and Kelman, 1961 in Appiah, 2001). Compared to the existence of communication source, some research shows that individual that identify themselves more often with a character represented in the television incline to be affected more easily with media content that attached the character (Huesman et al. in Appiah, 2001). In the context of the advertising, there is much research that proves that individuals prefer an ad model that is similar to them. That is to say when individuals identify themselves with a model used in the advertisements; they incline to put themselves in a more positive way to the content attaching the model employed in an ad (Kelman, 1961 in Appiah, 2001).

One of the characteristics in the ad model that can be identification sources for individuals is ethnicity. Theoretical explanations that can explain the existence of ethnicity as identification sources for individuals is the strength of ethnic identification (DeshpandeandStayman, 1994). In this vein, the power of ethnic identification can be seen as one deciding factor that can lead the individual response to the notice. The study conducted in the United States found that, as opposed to a teenager that weakly identify themselves to black ethnicity, a teenage who identify themselves strongly to black ethnicity is likely to identify themselves strongly toward black character employed in the advertisements (Appiah, 2001).

\section{Distinctiveness Theory}

Distinctiveness theory shows that when the proposition of minority membership is lower compared to the whole population, advertising stimulus targeting ethnicity tend to be more effective (Deshpandeand Douglas, 1994). The central proposition of the construction is that individual features that are different from others in a certain social interaction will be more salient compared to features that are similar (McGuire, 1984 in Deshpandeand Douglas, 1994). This theory predicts that ethnicity will be more prominent in the individual that comes from a minority group than the majority in the social environment that more or less same (Appiah, 2001). With this in mind, it is logical to affirm that individual ethnicity is more probable to appear spontaneously if that people live in a social context where they can find a small number of individuals that ethnically is similar (Torres andBrigg, $\mathrm{s}$ 2007). If it is applied in the advertising practice, the advertiser could hope that ethnic minority that is targeted in the advertising will heed better attention than an ethnic majority, especially if the ad is designed to have an ethnic feature that is similar to target individual in the advertising (Wooten, 1995).

\section{Self-Referencing on ad}

Self-referencing in the individual will appear when they process certain information by connecting it to some aspect in their lives (Lee et al., 2002). Self-referencing assumes that individuals are involved and organized structures, within it, semantic and episodic knowledge have been processed throughout one life located (Burnkrant and Unnava, 1995 in Lee et al., 2002). In other words, selfreferencing is defined as an information processing strategy that is used by an individual and includes personal memory and experience (Martin et al., 2004). As a process, self-referencing represent a cognitive process in which information within the advertisements is hinged with one self-concept. One self-concept represents a reference framework that within it contain self-aspects, such as ethnicity (Martin et al., 2004).

\section{Schematic Incongruity Theory}

One of the contextual factors that can affect the linkage between individual ethnicity with its responsibility toward advertisements is a schemata-inconsistent advertisement based on ethnicity. Schemata is a cognitive structure that represents specific knowledge regarding various stimulus received by individuals. Schemata will be actively involved in every process of coding and retrieving of information stored in the memory, whether periodic or semantic (Dimofte et al., 2004). The individual schema will always show expectation that is different in each. As a result, schemata will create different individual sensitivity toward any information related to schematic knowledge within them. The sensitive difference will be more apparent when the information that is faced by an 
individual is information that is relevant to individual schemata (Markus, 1977 in Dimofte et al., 2004).

In the advertising, the use of message component that has no schemata-consistency will increase the rate of individual attention to an ad. The execution of incongruous advertising elements could elevate the uniqueness of the advertisementto advertising context that exists and raise personal awareness to that ad (Goodstein, 1993 in Dimofte et al., 2004). The use of advertising elements that do not correspond with the consumer expectation or general schemata of advertisingwill rise the ad content processing by the consumer (Dimofter et al., 2004). In the multicultural advertising, the advertiser should ensure that the use of ethnicity model in the ad could synergize with other elements in the ad so that the schemata-inconsistent advertisement of the consumer could be held (Dimofte et al., 2004).

\section{Hypothesis and Research Model}

Based on the theoretical explanation above that relate to the aspects of ethnicity in the advertising, six hypotheses and theoretical models can be formulated as follows:

Hypothesis 1: Towards advertisements with the ad models related to Chinese ethnicity, Chinese respondents will give a degree of self-reference (SR) that is stronger than those who come from Javanese ethnicity.

Hypothesis 2a: In the individuals with Chinese and Javanese ethnicity, a degree of self-reference (SR) that is stronger to an advertisement that uses ad models from their ethnicity will actuate positive attitude that is stronger to the ad model performed in the ad (ATM).

Hypothesis 2b: In the individuals with Chinese and Javanese ethnicity, a degree of self-reference (SR) that is stronger to an advertisement that uses ad models from their ethnicity will actuate positive attitude that is stronger to the ad as a whole (ATA).

Hypothesis 2c: In the individuals with Chinese and Javanese ethnicity, a degree of self-reference (SR) that is stronger to an advertisement that uses ad models from their ethnicity will actuate positive attitude that is stronger to the product advertised (ATP).

Hypothesis 3a: Advertisements showing ad models from Chinese ethnicity will actuate a degree of self-reference (SR) that is stronger both in the Chinese and Javanese group when the advertisement shows the non-Chinese product (Javanese product) than when it shows Chinese product ethnicity.

Hypothesis 3b: For individuals that both come from the Chinese and Javanese group, advertisements that show ad models from Chinese ethnicity will actuate a positive attitude that is stronger to the ad model (ATM), advertisement (ATA), brand of the product (ATP) advertised when the ad show non-Chinese product then when those ads show Chinese product. 


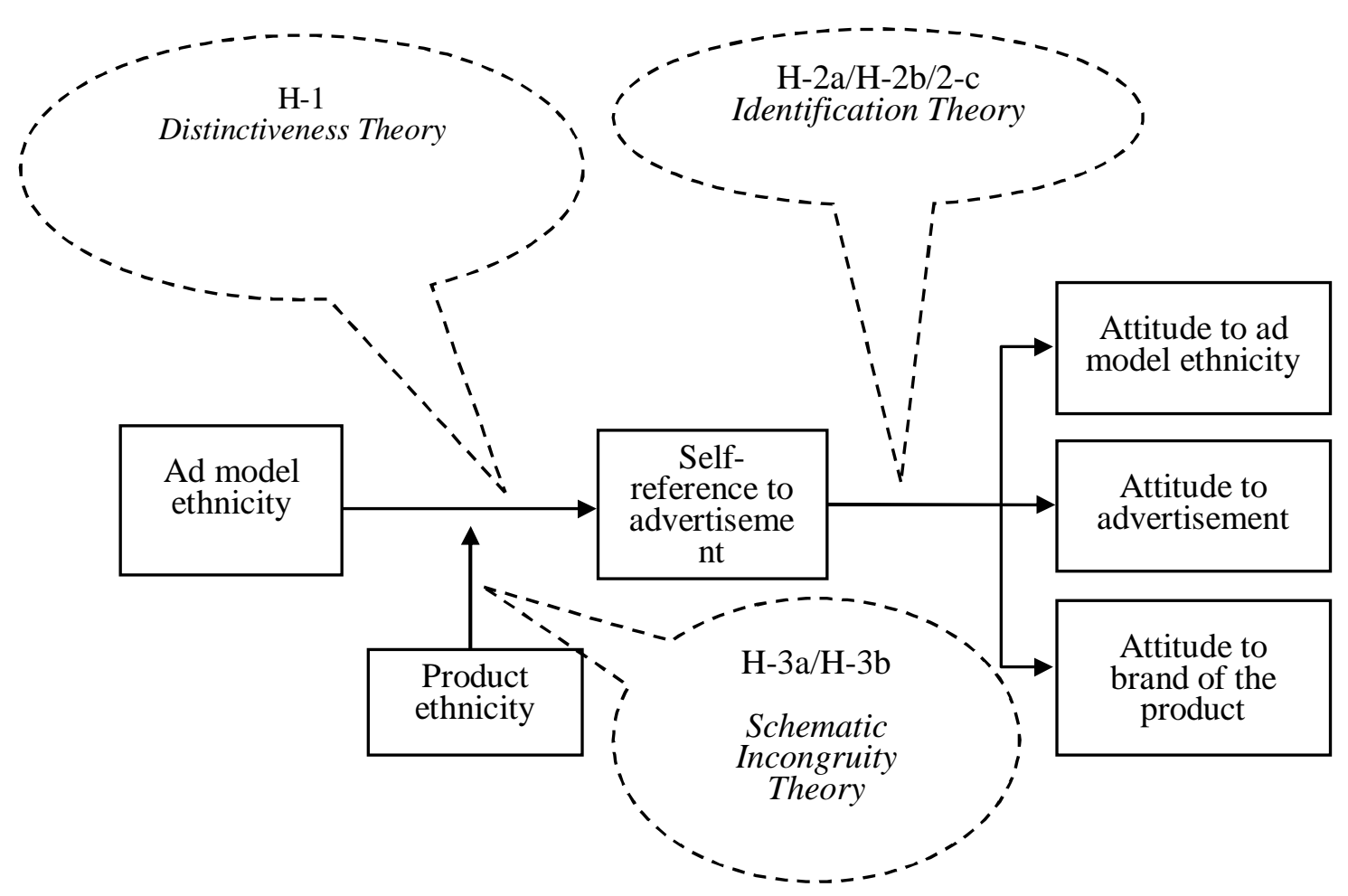

Figure 1.Research model

\section{The Measurement of Independent Variable: Self Reference}

Self-reference was measured using seven questions having a five-level scale from extremely disagree to extremely agree (Burnkrantand Unnava, 1995; DebevecandIyer, 1998; Debevecand Romeo, 1992; Meyer et al., 1996 in Martin et al., 2004). The questions consisted of (1) the advertisement that I just saw make me think about our personal experience of the product advertised. (2) For me, the advertisement seemingly has linkage with myself personally. (3) I can relate myself easily to the model that performs in the ad I just saw. (4) The ad I just saw can be reflected clearly in our mind. (5) I can see a similarity between myself and the ad model in the ad I just read. (6) I can easily imagine myself use the advertised product I just read. (7) The ad model in the advertisement I just watched could represent the social group where I am the part of it.

\section{The Measurement of Dependent Variable: Attitude towards Ad Model}

The attitude toward the ad model can be defined as an individual tendency to respond model used in an advertisement by perceiving the model consistently as an enjoyable object or not. The attitude toward the ad model was measured using five measurement items with semantic differential scale starting from (1) not attractive until very believable; (2) not attractive until very attractive; (3) not competent until very competent (4) not persuasive until very persuasive, and (5) not likeable until very likeable (Williams and Qualls, 1989 and William et al., 1995 in Martin et al., 2004).

\section{The Measurement of Dependent Variable: Attitude towards an Advertisement}

The attitude toward an advertisement can be defined as an individual tendency to respond to the advertisement as a whole by perceiving the advertisement consistently as an enjoyable object or not. The attitude toward the advertisement was measured using seven measurement items using a fivelevel semantic differential scale starting from (1) bad until good, (2) unconvincing until convincing, (3) uninformative until informative, (4) not interesting until interesting, (5) unpleasant until pleasant, (6) not likable until likable, and (7) not enjoyable until enjoyable (Holbrook andBatta, 1987 and Krishnamurthy andSujan, 1999 in Martin et al., 2004). 


\section{The Measurement of Dependent Variable: Attitude towards Brand Product}

The attitude toward a brand product can be defined as an individual tendency to respond to a brand product by perceiving the brand consistently as an enjoyable object or not. The attitude toward the brand product was measured using four measurement items using a five-level semantic differential scale starting from (1) bad until good, (2) dislike until like, (3) unpleasant until pleasant and (4) inferior until superior (Battaand Stephan, 1994 in Martin et al., 2004).

\section{Testing Hypothesis 1 with IndependentSamples T-test}

The researcher used the primary test data on experimental group 1 (the group that was showed by the advertisements performing Chinese ad models and Chinese products) and experimental group 2 (the group that was showed bythe advertisements performingChinese ad models and Javanese products) to test the hypothesis. Those two groups consisted of 20 participants from Chinese ethnicity and other 20 from Javanese ethnicity that obtained experimental ad stimulus using Chinese ad models. To prove the hypothesis 1 , the researcher grouped two variables of self-reference (SR) resulted from 40 Chinese participants and 40 Javanese participants entailing in experiment group 1 and 2. After analyzed with independent sample t-test, the result is that Chinese participants reached a higher average degree of self-reference than Javanese. The gap amounted to 0,6650 . The difference in mean above was significant since the score of $t$ on different $t$-test using equal variances assumed amounted to 3,395 with significance to 0,001 . It was much lower than 0,05 (the degree of reliability $95 \%$ )

On the other hand, the analysis of independent samples t-test on experimental group 3 and 4 (groups that perceived ad with Javanese ad model) shows that if an individual educated by the ads performing Javanese ad models, the mean appearing was lower, namely 0,0775. The gap was not significant as opposed to the $t$ score on equal variance assumed at 0,426 with significance accounting for 0,671 , significantly higher than 0,05 (the degree of reliability $95 \%$ ).

The analysis result above illustrates that if the advertisement delivered was designed to own similar ethnic features with the target individual in the advertising, the Chinese group was likely to show a degree of self-reference that was bigger than Javanese group. Chinese participants who were minority become more sensitive to identify their ethnicity when they discovered ad stimuli displaying their aspects of ethnicity. In other words, the Chinese participants created ethnic differentiation spontaneously once receiving an ad with the stimuli.

\section{Hypothesis 2a, 2b, 2c with Linear Regression}

To test the hypothesis, the researcher used data of self-reference variable (SR) and attitude toward the ad model (ATM) from experimental group 1,2,3, and 4. From experimental group 1 and 2 (the groups that view the ads with Chinese ad models), the researcher only used data from 40 Chinese participants; while from experimental group 3 and 4 (groups that saw the ads with Javanese ad models), the researcher merely used 40 Javanese participants. 
Table 2.Testing result of linear regression

\begin{tabular}{|c|c|c|c|c|}
\hline Variable & $\begin{array}{l}\text { Experimental } \\
\text { group }\end{array}$ & $B$ & $t$ & $\begin{array}{c}\text { Sig } \\
(\mathbf{9 5 \%})\end{array}$ \\
\hline $\begin{array}{l}\text { self-referencing (SR) on attitude towards ad } \\
\text { model (ATM) }\end{array}$ & $1 \& 2$ & 0,672 & 5,592 & 0,000 \\
\hline $\begin{array}{l}\text { self-referencing (SR) on attitude towards ad } \\
\text { model (ATM) }\end{array}$ & $3 \& 4$ & 0,582 & 4,407 & 0,000 \\
\hline $\begin{array}{l}\text { self-referencing (SR) } \\
\text { advertisement (ATA) }\end{array}$ & $1 \& 2$ & 0,620 & 4,878 & 0,000 \\
\hline $\begin{array}{l}\text { self-referencing (SR) on attitude towards } \\
\text { advertisement (ATA) }\end{array}$ & $3 \& 4$ & 0,529 & 3,841 & 0,000 \\
\hline $\begin{array}{l}\text { self-referencing (SR) on attitude towards brand of } \\
\text { the product (ATP) }\end{array}$ & $1 \& 2$ & 0,536 & 3,915 & 0,000 \\
\hline $\begin{array}{l}\text { self-referencing (SR) on attitude towards brand of } \\
\text { the product (ATP) }\end{array}$ & $3 \& 4$ & 0,530 & 3,855 & 0,000 \\
\hline
\end{tabular}

The analysis result above demonstrated that hypothesis $2 a, 2 b, 2 c$ in the study was acceptable. The result explained that, regardless of their ethnicity position, whether for the ethnic minority or majority, each always developed their self-structure that related to their memberships in that ethnic group. An individual invariably hada self-structure in the form of cognitive generalization about himself, and the membership to particular ethnic group compounded a part in the self-structure. Individuals activated their self-structure when they receive stimuli of information, such as advertisement. Individual then was considered to perform self-reference towards the ads on that time. When in the self-reference process individuals show a similarity between them and information within the ads, there appeared a positive feeling in the individuals toward the advertisement aspect including the ad model, the advertisement as a whole, and the brand of the product.

\section{Testing Hypothesis 3a with Independent Samples T-test}

The researcher tested hypothesis $3 \mathrm{a}$ using independent sample t-test. The test compared the average score of self-reference variable (SR) among 40 participants in the experimental group 1 (the group that view the ads with Chinese ad models and Chinese product) and among 40 participants in the experimental group 2 (the group that perceives the ads with Chinese ad models and Javanese product). The analysis of independent sample t-test using equal variances assumed demonstrated the difference in mean to 0,8850 with the score of $\mathrm{t}$ in the assumed accounted for 4,871 and the significance to 0,0000 in the degree of reliability $95 \%$. The test illustrated that the difference in the average score of self-reference variable was significant both in the experimental group 1 and 2. Participants in the experimental group 2 that noticed the ads with Chinese ad model and Javanese product had a higher amount of self-reference (SR) than participants in the experimental group 1 seeing the ads with Chinese ad models and Chinese product.

The analysis showed that Batik fashion that was related to Javanese ethnicity acted as atypical product category in the context of the use of the Chinese ad model. The presence of Batik clothing bred schema-inconsistent effect to Chinese ad models. When the advertisement performing Chinese ad models advertised Javanese Batik, individuals regarded the phenomenon as something that does not correspond with their schemata knowledge and expectations on an advertisement. Individuals assumed that when advertisements performed Chinese ad models, their ads should have advertised Chinese products. As a result, advertisements that used Chinese ad models and advertised Javanese product category were perceived incongruity. The schemata incongruity condition enabled individuals to give more attention to the advertisements that used Chinese ad models for advertising Batik as a product that relate to Javanese ethnicity. That significant attention rate can increase the process of understanding the content of the advertisement in the individual. 


\section{Testing Hypothesis 3b with Independent Sample T-Test}

Testing hypothesis 3b used data from experimental group 1 (an experimental group that viewed the advertisements performed Chinese ad model for advertising Chinese product) and experimental group 2 (a group that saw the ads that used Chinese ad model and promoted Javanese product ethnicity). The testing aimed for comparing the average score of attitude variables to ad model (ATM), the advertisement itself (ATA), and brand of the product (ATP) of 40 respondents of experimental group 1 and other 40 of experimental group 2.

Analysis of the independent sample t-test on the attitude variable on ad models (ATM) showed a difference in the mean amounted to 0,5850 . The $t$ score on equal variances assumed received $3,816 \%$ with signification to 0,000 , far lower than 0,05 (the degree of reliability $95 \%$ ). Participant in the second experimental group that was educated by the ad using Chinese ad model and Javanese product had a more significant typical score of attitude variable on ad model than group 1 that was revealed by Chinese ad model and Chinese product.

Furthermore, analysis of independent sample t-test to average attitude variable on the advertisement (ATA) demonstrated a difference in mean at 0,6200. The score of $t$ in equal variance assumed was 4.020 with signification to 0,0000 , much lower than 0,05 (degree of reliability 95\%). Participant in the second experimental group that was educated by the ad model Chinese ethnicity and Javanese product had more significant typical attitude variable on the advertisement than group 1 that was revealed by the ad that performed Chinese ad model and Chinese product.

Analysis of the independent sample t-test on the attitude variable to the brand of the product (ATP) reflected a difference in the mean amounted to 0,6013 . The $t$ score on equal variances assumed received $3,661 \%$ with signification to 0,000 , far lower than 0,05 (the degree of reliability $95 \%$ ). Participant in the second experimental group that was educated by the ad with Chinese ad models and Javanese product had more significant typical attitude variable on a brand of the product (ATP) than group 1 that was revealed by the advertisement with Chinese ad model from and Chinese ethnicity product

The analysis result above demonstrated that Batik clothing as a product that relates to Javanese product ethnicity acted as atypical product category in the context of the use of Chinese ad models. The product can produce a schema-inconsistent effect on the advertisement that used Chinese ad models. When an ad using Chinese ad models advertised Javanese Batik, the respondents viewed the phenomenon as something incongruous with their knowledge and schematic expectation. It was unusual to find that Chinese ad models advertised a Javanese product category. The schemainconsistent could increase the rate of individual attention toward the ads. That significant rate rose individual process toward the message of the advertisement, which, subsequently, raised positive attitude to the ad model (ATM), advertisement (ATA) and brand of the product (ATP).

\section{CONCLUSION}

In conclusion, the theoretical model initiated by Lee et al. to demonstrate the effect of ad model ethnicity on consumers' behavior in the New Zealand social background can be applied to explain the same phenomenon in Indonesia. The used of ad model ethnicity involving individuals from Chinese ethnicity in the society where Javanese is the majority affected individual behavior in advertising.

The existence of an ethnic minority in the different ethnic environment may actuate individuals in that minority group to become more sensitive in showing self-references to the advertisements using ad modelsfrom an ethnic minority. Also, individuals from an ethnic minority turned to be more sensitive in identifying their ethnicity. Different ethnic identification among persons of a minority group could affect individuals' capability to reflect the degree of self-reference in perceiving ad using ad models from an ethnic minority. That being said, both individuals coming from an ethnic minority and amajority invariably did self-references to the ad that had similar ethnic characteristicthat was consistent with them. As a result, when the individuals viewedthe advertisements performing model from their ethnicity, whether coming from the ethnic minority or majority witnessed a degree of selfreference to the ad. Subsequently, the degree was likely to affect individual attitude in advertising. When a minority model advertised majority products, the ads prompt schemata-inconsistency to both minority and majority individuals. The schema-inconsistent effect could modify the degree of selfreference and individual attitude to advertising, both for theethnic minority and majority.

The study was a laboratory experiment and, as the nature of the methodology, this experiment can provide higher internal validity despite its weakness in the external one. To that end, this research was 
merely valid in depicting relations among variables and participants that were involved in the research model. The result might not be generalized to other individuals outside research participants. Moreover, the research merely invited limited female participant while the ad model ethnicity could impact both male and female. The female-only participants restricted the degree of realism of the study. In the real situation, the type of notice could work on both male and female. Indeed, the participants in the research only came from teenage high school girls while the real female products originate from various educational backgrounds.

The research at least has successfully described the influence of ethnic aspects on advertising in spite of the nature of the methodology on external validity. The findings have demonstrated that an ethnic minority in the ethnic majority environment could engender individuals from an ethnic minority to be more receptive in perceiving ethnic signs in advertising. Moreover, that phenomenon tended to be leading individuals in both sides to prefer ad model from an ethnic minority. It was conceived to be more consistent for advertising product category associated with an ethnic minority. It was likely to actuate schema-inconsistent effect as a shock effect for raising attention to the ad. When the ad model from an ethnic minority performed the majority product, the advertiser could be hoping to gain more audiences.

For better generalization in testing the effect of ethnic aspects on advertising responses, the research result can commence field research that is more promising in term of higher external validity. The researcher suggests incorporating gender variables in the research design. The next researcher also needs to consider involving male respondents or participants.

\section{REFERENCES}

Aaker, Jenifer, Anne M. Brumbaugh and Sonya A. Grier (2000), "Nontarget Markets and View Distinctiveness: The Impact of Target Marketing on Advertising Attitudes," Journal of Consumer Psychology, 9 (3): 127-140.

Appiah, Osei (2001), “Ethnic Identification on Adolescents' Evaluations of Advertisements," Journal of Advertising Research, 41 (5): 7-22.

Assael, Henry (2004), Consumer Behavior: A Strategic Approach, Boston MA: 02116-3764: Houghton Mifflin Company.

Bagozzi, Richard P., Nancy Wong, Shuzo Abe and Massimo Bergami (2000), "Cultural and Situational Contingencies and the Theory of Reasoned Action: Application to Fast Food Restaurant Consumption," Journal of Consumer Psychology, 9 (2): 97-106.

Baron, Reuben M. and David A. Kenny (1986), "The Moderator-Mediator Variable Distinction in Social Psychological Research: Conceptual, Strategic, and Statistical Consideration," Journal of Personality and Social Psychology, 51 (6): 1173-1182

Bergman, Mohan J. Dutta (2006), "The Demographic and Psychographic Antecedents of Attitude Toward Advertising," Journal of Adverising Research, (March), 102-112.

Briley, Donnel A., L.J. Shrum and Robert S. Wyer Jr. (2007), "Subjective Impressions of Minority Group Representation in the Media: A Comparison of Majority and Minority Viewers' Judgments and Underlying Processes," Journal of Consumer Psychology, 17 (1): 36-48.

Burgos, David (2008), "Use and Abuse of Cultural Elements in Multicultural Advertising," Journal of Advertising Research, (June), 177-178.

Cooper, Donald R. and Pamela S. Schindler (2006), Bussines Research Methods $9^{\text {th }}$ Ed., New York: McGraw Hill.

Crask, Melvin, Ricard J. Fox and Roy G. Stout (1995), Marketing Reseaarch Principles and Applications, New Jersey 07632: Prentice Hall.

Cui, Geng (1997), "Marketing Strategies in a Multi Ethnic Environment," Journal of Marketing Theory and Practice, 1 (5): 122-134.

D'Rozario, Denve, Susan P. Douglas (1999), "Effect of Assimilation on Prepurchase External Information-Search Tendenies," Journal of Consumer Psychology, 8 (2): 87-209.

Deshpande, Rohit and Douglas M Stayman (1994), “A Tale of Two Cities: Distinctiveness Theory and Advertising Effectiveness," Journal of Marketing Research, 31 (February), 57-64.

Deshpande, Rohit, Wayne D. Hoyer and Naveen Donthu (1986), "The Intensity of Ethnic Affiliation: A Study od the Sociology of Hispanic Consumption," Journal of Consumer Research, 13 (2): 214-220. 
Dimofte, Claudiu V., Mark R. Forehand and RohitDeshpande (2004), “Ad schema incongruity as elicitor of ethnic self-awareness and differential advertising response," Journal of Advertising, 32 (4): 7-17.

Ferle, Carrie La and Wei Lee (2005), "Can English Language Media Connect With Ethnic Audiences? Etnic Minorities" Media Use and Representation Perceptions", Journal of Advertising Research, (March), 140-153.

Forehand, Mark R., and RohitDespdane (2001), "What We See Makes Us Who We Are: Priming Ethnic Self-Awareness and Advertising Response," Journal of Marketing Research, 38 (3): 336-348.

Ghozali, Imam (2006), AplikasiAnalisis Multivariate dengan Program SPSS, Semarang: BadanPenerbitUniversitasDiponegoro.

Green, Corliss L. (1999), "Ethnic Evaluation of Advertising: Interaction Effects of Strength of Ethnic Identification, Media Placement, and Degree of Racial Compotition," Journal of Advertising, 38 (1): 49-64.

Grier, Sonya A. and Anne M. Brumbaugh (1999), "Noticing Cultural Differences: Ad Meaning Created by Target and Non-Target Market," Journal of Advertising, 28 (1): 79-93.

Grier, Sonya A. and RohitDespdane (2001), "Social Dimensions of Consumer Distinctiveness: The Influence of Social Status of Group Identit and Advertising Persuasion," Journal of Marketing Research, 38 (May), 216-224.

Hair, Joseph F. Jr., William C.Black, Barry J. babin, Rolph E. Anderson, and Ronald L. Tatham (2006), Multivariate Data Analysis, $6^{\text {th }}$ Ed. , New Jersey 07458: Pearson Prentice Hall.

Helmig, Bernd, Jan-Alexdaner Huber and Peter Leeflang (2007), "Explaining Behavioural Intentions Toward Co-Brdaning Products," Journal of Marketing Management, 23 (3-4): 285-304.

Kim, Youn-Kyung and Jikyeong Kang (2001), “The Effects of Ethnicity and Product on Purchase Decision Making," Journal of Advertising Research, (March-April), 39-48

Korzenny, Felipe (2008), "Multicultural Marketing and the Reason Why," Journal of Advertising Research, (June), 173-176.

Koslow, Scott, Preem N. Shamdasani and Ellen E. Touchstone (1994), Exploring Language Effect in Ethnic Advertising: A Sociolinguistic Perspective," Journal of Consumer Research, 20 (March), 575-585.

Kotler, Philip and Kevin Lane Keller (2006), Marketing Management $12^{\text {th }}$ Ed., New Jersey 07458 : Pearson Prentice Hall.

Laroche, Michel, Chung Koo Kim and Madeleine Clarke (1997), "The Effects of Ethnicity Factors on Consumer Deal Interest: An Empicrical Study od French- and Enghlish-Canadians,” Journal of Marketing Theory and Practice, (Winter), 100-111.

Lee, Christina Kwai-Choi, NaliniFernandes and Breet A.S. Martin (2002), "Using Self Referencing to Explain the Effectiveness of Etnich Minority Models in Advertising", International Journal of Advertising, 21 (3): 367-379.

Martin, Brett A., Christina Kwai-Choi Lee and Feng Yang (2004), “The Influence of Ad Model Ethnicity and Self-Referencing on Attitudes," Journal of Advertising, 33 (4): 27-37.

Neuman, W. Lawrence (2006), Social Research Methods: Qualitative and Quantitative Approaches6 ${ }^{\text {th }}$ Ed., Boston MA 02116: Pearson Education Inc..

Newcomb, Theodore M., SocialPhsycologi: The Studi of Human Interaction, TerjemahanolehNoesjirwan, Joesoef (1985), Bandung: CV Diponegoro.

Pitts, Robert E., D. Joel Whalen, Robert O'Keefe and Vernon Murray (1989), "Black and White Response to Culturally Targeted Television Commercials: A Value-Based Approach," Psychology and Marketing, 6 (4): 311-328.

Sandage, C.H. and Vernon Fryburger (1963), Advertising Theory and Practice $6^{\text {th }}$ Ed., Illionis: Richard D. Irwin Inc.

Seitz, Victoria (1998), "Acculturation and Direct Purchasing Behavior Among Ethnic Groups in the USA: Implications for Business Practitioners," Journal of Consumer Marketing, 15 (1): 2331.

Shimp, Terence A. (2000), Advertising Promotion: Suplemental Aspect of Integrated Marketing Communications $5^{\text {th }}$ Ed., Orlando: The Dryden Press.

Stayman, Douglas M and RohitDeshpande (1989), "Situational Ethnicity and Consumer Behavior," Journal of Consumer Research, 16 (December), 361-371. 
Torres, Ivonne M. and Elten Briggs (2007), "Identification effect on advertising respon: The moderating role of involvement," Journal of Advertising, 36 (3): 97-108.

Venkatraman, Meera P. (1990), "Opinion Leadership, Enduring Involvement and Characteristic of Opinion Leaders: A Moderating or Mediating Relationship?," Advance in Consumer Research, 17(61), 60-67.

Villarreal, Ricard and Robert A. Peterson (2008), "Hispanic Ethnicity and Media Behavior," Journal of Advertising Research, (June), 179-190.

Webster, Cynthia (1997), "Resource Theory in a Cultural Context: Linkage Between Ethnic Identity, Gender Roles, and Purchase Behavio," Journal of Marketing Theory and Practice, (Winter), $1-6$.

Wijaya, Tony (2009), Analisis Data PenelitianMenggunakan SPSS, Yogyakarta: PenerbitUniversitasAtma Jaya Yogyakarta.

Wooten, David B. (1995), "One-of-a-Kind in a Full House: Some Consequences of Ethnic and Gender Distinctiveness," Journal of Consumer Psychology, 4 (3): 205-224. 